\title{
Regulation of the Drosophila Fascin by Raf Signaling
}

\author{
Jung-hoon Pyo, Na-hyun Choi, Shin-hae Lee, Young-shin Kim and Mi-Ae Yoo* \\ Department of Molecular Biology, College of Natural Science, Pusan National University, Busan 609-735, Korea
}

Received April 23, 2009 /Accepted June 9, 2009

\begin{abstract}
Fascin, a cytoskeleton actin binding protein, functions in cell adhesion and cell migration. Fascin is also known as a candidate biomarker for various cancers, however, regulatory mechanisms of fascin expression remains little understood. In this study, we found an abnormal bristle phenotype, which is similar to that of the Drosophila fascin mutant, in Draf mutant flies. Hence, we investigated whether fascin expression is regulated by Raf signaling. RT-PCR and Western blot analysis showed that Drosophila fascin expression was down-regulated in Draf mutant flies and the level was increased in larvae expressing the oncogenic form of Draf (Draf $\left.{ }^{\text {ouf }}\right)$ under the GAL4-UAS system. Immunostaining analysis showed increased fascin in the hemocytes over-expressing Draf $f^{\text {gof }}$. Our results indicate that fascin expression is regulated by Raf signaling and suggest that Raf signaling may play an important role in the actin cytoskeleton-associated developmental process and tumor progression via regulation of fascin gene.
\end{abstract}

Key words : Drosophila, fascin, singed, Raf, gene expression

\section{Introduction}

Distribution of actin cytoskeleton appears to be an important step in the development including tissue morphogenesis and progress of carcinogenesis [7,19]. The organization of actin-based structures is highly regulated by binding of Fascin [15]. Fascin is known as a 55kDa actin-binding protein $[15,17]$. Fascin has been well-conserved in animal evolution; homologues are present in Drosophila, echinoderms and the platyhelminth Schmidtea mediterranea [1]. In vertebrate, three forms of fascin have been indentified: Fascin-1, Fascin-2 and Fascin-3 [1,15]. All Fascins have a highly conserved region consensus motif for phosphorylation by protein kinase C (PKC) [2]. During embryogenesis, Fascin-1 is expressed in many motile cell populations, principally in the developing nervous system and in the mesoderm and its derivatives [9]. Fascin expression is low or absent in the majority of normal adult epithelia but up-regulation of the protein in all forms of human carcinoma studied to date has been reported [11]. Because of these facts, the actin-bundling protein fascin has emerged as a very interesting candidate biomarker for various cancers [11]. In Drosophila, singed gene has been known to encode Drosophila fascin [6,8]. Fascin mutant flies have the phenotypes such as short, gnarled bristles and flaccid oocytes,

*Corresponding author

Tel : +82-51-510-2278, Fax : +82-51-513-9258

E-mail : mayoo@pusan.ac.kr leading to female sterility [18]. Fascin is expressed in migrating hemocytes [1], migratory border cells, posterior follicle cells and nurse cells of the developing egg chamber, and in the socket cells and main cells of hairs and bristle [8]. Although the results of several studies have shown that fascin has an important role for developmental process and tumor invasion, the regulatory mechanisms of fascin gene expression remains little explained.

The Ras-Raf-MEK-ERK/MAPK pathway is an evolutionary conserved pathway in the control of many fundamental cellular process including cell proliferation, survival, differentiation, apoptosis, motility and metabolism [14]. It was reported that Ras might remodel actin cytoskeleton through activation of ERK (extracellular-signal regulated kinase) cascade [12]. The ERK cascade impacts on cell proliferation and survival, and recent studies have demonstrated a close link between organization of the actin cytoskeleton and activity of the ERK pathway. Growth factor-mediated activation of ERK is adhesion-dependent and relies upon an intact cytoskeleton [12,13]. It was also reported that Fascin protein levels are regulated by Ras dependent growth factor signaling in mammary epithelial tumor [10]. However, regulation of Fascin by Raf signaling is unknown yet.

In this study, we found an abnormal bristle phenotype, which is similar to those of Drosophila fascin mutant, in Draf mutant flies. Hence, we investigated whether Drosophila fascin expression is regulated by Raf signaling. 


\section{Materials and Methods}

\section{Fly stocks}

Fly stocks were maintained at $25^{\circ} \mathrm{C}$ on standard food. hsp70-GAL4 (hs-GAL4), cg-GAL4, UAS-Drafgof, and $s n^{X^{2}}$ strains were kindly supplied by the Bloomington Stock Center. $y$ Draf $^{c 10}$ [16] flies were kindly provided from Dr. Y. Nishida. Oregon- $R$ was used as wild type.

\section{Ectopic expression of Raf by heat shock induction}

Females carrying homozygous $h s-G A L 4$ on the third chromosome were crossed with males carrying homozygous $U A S-D r a f^{g o f}$ on the third chromosome. The progeny third larvae were heat-shocked at $37^{\circ} \mathrm{C}$ for $30 \mathrm{~min}$ and then incubated at $25^{\circ} \mathrm{C}$.

Reverse transcription-polymerase chain reaction
(RT-PCR)

The whole ovary mRNA or total mRNA from the individuals was isolated using Trizol Reagent (Molecular Research Center, USA) according to the protocol furnished by manufacturer and the cDNAs were synthesized using M-MLV-RT (Reverse transcriptase, Promega, USA). The RT-PCR products were analysed on $2 \%$ agarose gels stained with ethidium bromide. Oligonucleotide primers for PCR were designed as follows.

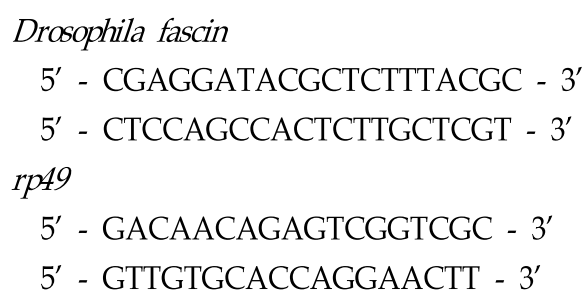

\section{Western blot analysis}

Protein extracts were isolated using PRO-PREP solution (Intron Biotechnology, Korea). Proteins were separated on $10 \%$ polyacrylamide SDS gel electrophoresis and transfered to PVDF membrane (Amersham, Sweden). The membrane was rinsed in TBS-T solution $(0.1 \%$ Tween- 20 in TBS, pH $7.4)$ and incubated in blocking buffer (5-10\% skim milk in TBS-T) at room temperature for $1 \mathrm{hr}$. Then the membrane was incubated with specific antibodies for Drosophila Fascin (1:50, sn7c, DHSB, USA), p44/p42 MAPK (ERK1/ERK2, 1:2000, Cell Signaling, USA), Phospho-p44/p42 MAPK (pERK1/pERK2, 1:1000, Cell Signaling) and $\alpha$-tubulin (1:5000, DHSB) at room temperature for $2 \mathrm{hr}$ (or at $4^{\circ} \mathrm{C} \mathrm{O} / \mathrm{N}$ ) and washed with TBS-T five times for every $10 \mathrm{~min}$, followed by incubating with secondary antibody (1:5000, goat anti-mouse HRP, 1:5000, mouse anti-rabbit HRP, Santa Cruz, USA) at room temperature for $1 \mathrm{hr}$. Protein labeled with antibody was detected with West-One ${ }^{\mathrm{TM}}$ (Intron).

\section{Hemocyte immunostaining}

Hemocytes collected from larvae were fixed $4 \%$ paraformaldehyde for $20 \mathrm{~min}$, and washed four times with PBS-T (0.1\% Tween-20 in PBS, pH 7.0). The samples were incubated overnight with mouse anti-Fascin (1:20, sn7c, DHSB) in 1\% BSA PBS-T at $4^{\circ} \mathrm{C}$. After washing four times with PBS-T, the samples were incubated with Cy3- conjugated goat anti-mouse IgG (1:400, Jackson ImmunoResearch, USA). DAPI (Molecular Probe, USA) was used at $1 \mu \mathrm{g} / \mathrm{ml}$. The sample was mounted in Vectashield Mounting Medium (Vector Laboratories, USA) and analyzed by a Karl Zeiss AxioPlan2 fluorescent microscope.

\section{Scanning Electron Microscopy (SEM)}

Adult flies were sputter-coated with platinum and observed under a Hitachi S-3500N scanning electron microscope.

\section{Results and Discussion}

In Drosophila, wild type flies have long and straight bristles (Fig. 1A). Interestingly, we found an abnormal bristle phenotype in a Drosophila Raf (Draf) mutant, Draf ${ }^{\text {c110 }}$ (Fig. 1B), Draf ${ }^{c 110}$ strain was found to be associated with single amino acid change within the putative Draf regulatory domain [16]. Draf $f^{\text {c110 }}$ flies have a rough eye phenotype and die either during pupariation or during hatching [16]. The spiral-like bristle phenotype of $\operatorname{Draf}^{c 10}$ (Fig. 1B) is similar to a phenotype of Drosophila fascin mutant strain (Fig. 1C) [8]. From these facts, we investigated whether Drosophila fascin gene expression is regulated by Raf signaling pathway. We first examined levels of fascin mRNA in Draf ${ }^{c 10}$ individuals using RT-PCR and Western blot analysis. As shown in Fig. 2, expression of fascin mRNA was reduced in the third instar larvae of Draf ${ }^{c 110}$ hypomorphic allele compared to wild type (Fig. 2A). We also detected a significant reduction of Fascin protein level in the third instar larvae of Draf ${ }^{c 110}$ hypomorphic allele by Western blot analysis (Fig. 2B).

To confirm the role of Raf signaling in fascin gene expression, we assessed modulation of fascin gene expression 

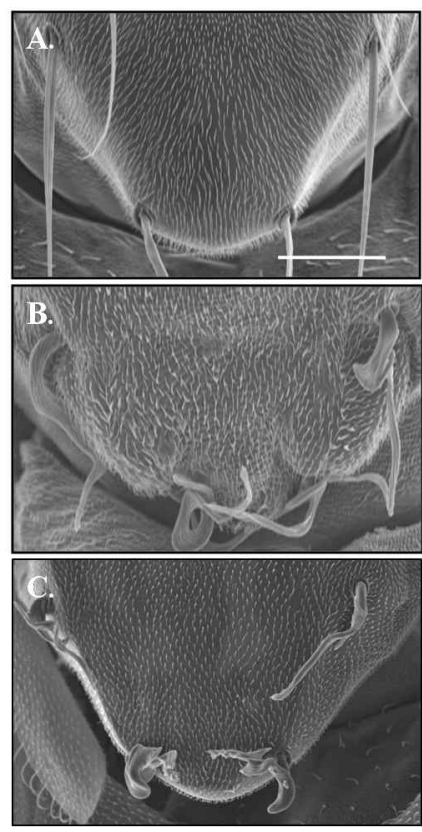

Fig. 1. Abnormal bristle phenotypes in Drosophila fascin and Raf mutant flies. (A) Wild type. (B) Draf ${ }^{c 10}$ male hemi-lethal flies. (C) Drosophila fascin mutant $\left(s n^{x^{2}}\right)$. Adult flies were sputter-coated with platinum and observed under a Hitachi S-3500N scanning electron microscope in the low-vaccum mode. Scale Bar: $100 \mu \mathrm{m}$
(A)

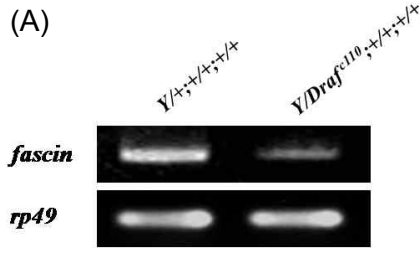

(B)

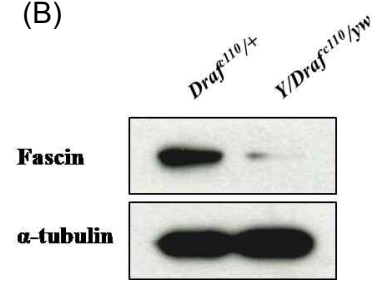

Fig. 2. Decreased expression levels of Drosophila fascin in Draf ${ }^{\text {c110 }}$ larvae. (A) The levels of fascin mRNA in wild type and Raf mutant via RT-PCR. Total RNA was prepared from whole body of wild type and hypomorphic allele of Draf $^{\text {c110 }}$ third instar larvae. The loading control was $r p 49$. (B) The levels of Fascin protein in wild type and Draf mutant via Western blot. Total protein was prepared from whole body of wild type and Draf ${ }^{110}$ third instar larvae. Ten $\mu \mathrm{g}$ of total protein samples were resolved by SDS-PAGE and analyzed by Western blot with anti-Fascin. The loading control was $\alpha$-tubulin.

by expression of the oncogenic form of Raf using GAL4-UAS system $[4,20]$. We examined level of fascin mRNA in larvae expressing the oncogenic form of Raf (Draf ${ }^{\text {ox }}$ ) under $h s$-GALA by RT-PCR. The level of fascin mRNA of larvae over-expressing Draf ${ }^{\text {got }}$ was higher than that of control (Fig. 3A). And also, we checked Fascin protein level in these flies by Western blot analysis. Raf signaling phosphorylates ERKs
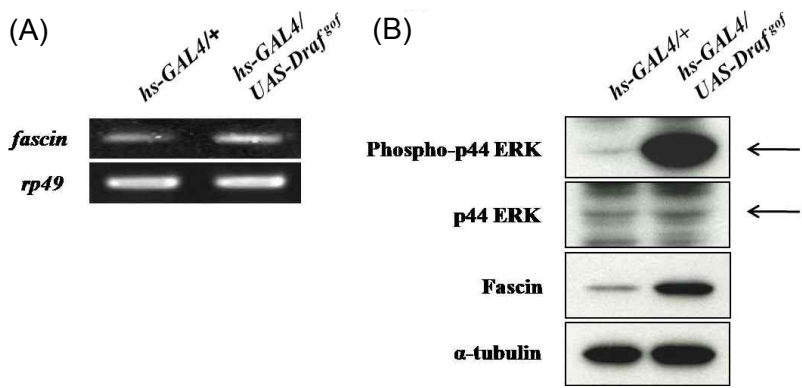

Fig. 3. Increased mRNA and protein levels of Drosophila fascin in larvae over-expressing the oncogenic form of Raf. (A) fascin mRNA level in the third instar larvae carrying $h s-G A L A$ and $U A S-D r a f^{g o f}$ after heat shock at $37^{\circ} \mathrm{C}$ for 30 min and incubated at $25^{\circ} \mathrm{C}$ for various time periods. RT-PCR was performed to determine fascin mRNA levels. The loading control was $r p 49$. (B) Fascin protein level in the third instar larvae carrying $h s-G A L A$ and UAS-Draf ${ }^{\text {gof }}$. ERK acts downstream factor of Draf. Thirty $\mu \mathrm{g}$ of total protein samples were loaded per lane for p44/p42 ERK and phospho-p44/p42 ERK. Ten $\mu \mathrm{g}$ of total protein samples were resolved by SDS-PAGE and analyzed by Western blot with anti-Fascin and anti- $\alpha$ Tubulin. The loading control was $\alpha$-tubulin and p44 ERK. Total protein was prepared from whole body of $h s-G A L A / 4$ or $h s-G A L A /$ $U A S-D r a f^{\text {gof }}$ third larvae after heat shock at $37^{\circ} \mathrm{C}$ for 30 min and incubated at $25^{\circ} \mathrm{C}$ for $24 \mathrm{hr}$.

[21]. To confirm over-expression of Draf ${ }^{\text {got }}$, we examined the phosphorylation level of ERK. The phosphorylation level of ERK in the extract from larvae over-expressing Draf got was higher than that of control (Fig. 3B). In this condition, Fascin protein level was higher than that of control (Fig. 3B). These results indicate that fascin expression is positively regulated by Raf signaling and suggest that Raf signaling may play important roles in actin cytoskeleton-associated developmental process and tumor progression via regulation of fascin gene.

Drosophila hemocyte could be a simple system to elucidate the molecular mechanisms underlying Ras-induced neoplastic cell over-proliferation that results in a leukemia-like phenotype [3]. It was reported that Drosophila Fascin protein is expressed in migrating hemocytes of embryos [1]. Here, we assessed whether the Fascin expression in the hemocyte is modulated by Raf activity. Since expression of Fascin in the hemocyte at larval stage has not been reported yet, we first examined whether Fascin is expressed in larval hemocytes. We observed a weak expression of Fascin in the cytoplasm of hemocyte under normal condition using anti-Fascin antibody (Fig. 4A and C). As expected, the expression level of Fascin in the hemocytes over-expressing 

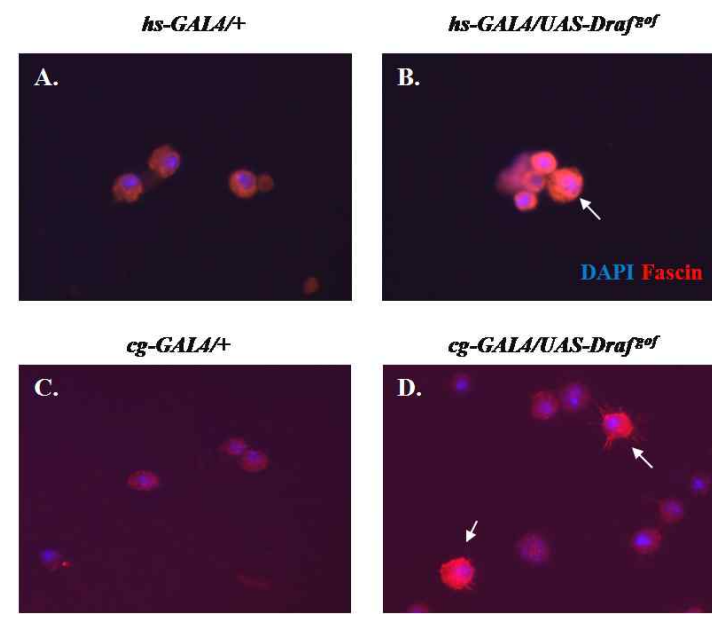

Cg-GALAUAS-Drafzof

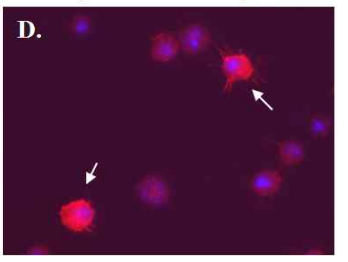

Fig. 4. Increased Drosophila Fascin expression in the hemocytes over-expressing the oncogenic form of Raf under $h s-G A L 4$ and cg-GALA (A, B) Hemocytes isolated from third instar larvae carrying $h s-G A L 4$ and UAS-Draf ${ }^{\text {got }}$ after heat shock at $37^{\circ} \mathrm{C}$ for $30 \mathrm{~min}$ and incubated at $25^{\circ} \mathrm{C}$ for $24 \mathrm{hr}$. (A) hs-GALAAt. (B) hs-GALANAS-Draf ${ }^{g o f}$. (C, D) Hemocytes isolated from third instar larvae carrying cg-GALA, hemocyte specific, and UAS-Draf ${ }^{g o f}$. (C) cg-GALA/t. (D) cg-GALANAS-Draf ${ }^{\text {gof }}$. Increased Fascin expression in the cytoplasm of hemocytes over-expressing Draf $^{\text {gof }}$ was detected (Arrow). Hemocyte immunostaining was conducted as described in the Material and Method section. Blue: DAPI (Nuclear). Red: Fascin

Draf ${ }^{\text {got }}$ under $h s-G A L 4$ was higher than that of control (Fig. 4B). To confirm the up-regulation of Fascin expression by Raf in hemocytes, we conducted over-expression of Draf $f^{\text {gof }}$ in the hemocyte using cg-GALA which is a hemocyte specific GAL4 [3]. Increased Fascin expression in the hemocytes over-expressing Draf gof ${ }^{\text {gof }}$ under $c g-G A L 4$ was also detected (Fig. 4D). These results indicate that Fascin expression is positively regulated by Raf signaling in the Drosophila hemocyte. It was well known that Fascin contributes to cell protrusion and is necessary for cell migration [15]. The over-expression of an activated Raf construct resulted in a large increase in the number of hemocytes [3]. In mammals, Fascin expression is enhanced in dendritic cells during maturation [5]. It was reported that Raf play a critical role in the differentiation and survival of monocyte-derived immature dendritic cells [22]. As a consequence, our data suggest that the regulation of Fascin by Raf may be a critical process for blood cell proliferation, differentiation, and migration.

In this study, we showed that Drosophila fascin gene is regulated by Raf signaling pathway. The regulatory mechanism may play a critical role for cytoskeletal-associated developmental processes including hemocyte proliferation and migration.

\section{Acknowledgement}

We are grateful to Dr Y. Nishida for Raf mutant fly stock. This work was supported for two years by Pusan National University Research Grant. J.-H. P was supported by the Brain Korea 21 Project in 2008.

\section{References}

1. Adams, J. C. 2004. Roles of fascin in cell adhesion and motility. Curr. Opin. Cell Biol. 16, 590-596.

2. Adams, J. C., J. D. Clelland, G. D. Collett, F. Matsumura, S. Yamashir, and L. Zhang. 1999. Cell-matrix adhesions differentially regulate fascin phosphorylation. Mol. Biol. Cell 10, 4177-4190.

3. Asha, H., I. Nagy, G. Kovacs, D. Stetson, I. Ando, and C. R. Dearolf. 2003. Analysis of Ras-induced overproliferation in Drosophila hemocytes. Genetics 163, 203-215.

4. Brand, A. H. and N. Perrimon. 1993. Targeted gene expression as a means of altering cell fates and generating dominant phenotypes. Development. 118, 401-415.

5. Bros, M., X. L. Ross, A. Pautz, A. B. Reske-Kunz, and R. Ross. 2003. The human fascin gene promoter is highly active in mature dendritic cells due to a stage-specific enhancer. J. Immunol. 171, 1825-1834.

6. Bryan, J., R. Edwards, P. Matsudaira, J. Otto, and J. Wulfkuhle. 1993. Fascin, an echinoid actin-bundling protein, is a homolog of the Drosophila singed gene product. Proc. Natl. Acad Sci. U. S. A. 90, 9115-9119.

7. Buda, A. and M. Pignatelli. 2004. Cytoskeletal network in colon cancer: from genes to clinical application. Int. J. Biochem Cell Biol. 36, 759-765.

8. Cant, K., B. A. Knowles, M. S. Mooseker, and L. Cooley. 1994. Drosophila singed, a fascin homolog, is required for actin bundle formation during oogenesis and bristle extension. J. Cell Biol. 125, 369-380.

9. De Arcangelis, A., E. Georges-Labouesse, and J. C. Adams. 2004. Expression of fascin-1, the gene encoding the actin-bundling protein fascin-1, during mouse embryogenesis. Gene Expr. Patterns 4, 637-643.

10. Guan, Y., P. L. Woo, N. M. Rubenstein, and G. L. Firestone. 2002. Transforming growth factor-alpha abrogates the glucocorticoid stimulation of tight junction formation and reverses the steroid-induced down-regulation of fascin in rat mammary epithelial tumor cells by a Ras-dependent pathway. Exp. Cell Res. 273, 1-11.

11. Hashimoto, Y., M. Parsons, and J. C. Adams. 2007. Dual actin-bundling and protein kinase C-binding activities of fascin regulate carcinoma cell migration downstream of Rac and contribute to metastasis. Mol. Biol. Cell 18, 4591-4602.

12. Helfman, D. M. and G. Pawlak. 2005. Myosin light chain kinase and acto-myosin contractility modulate activation of 
the ERK cascade downstream of oncogenic Ras. J. Cell Biochem 95, 1069-1080.

13. Howe, A. K., A. E. Aplin, and R. L. Juliano. 2002. Anchorage-dependent ERK signaling--mechanisms and consequences. Curr. Opin. Genet. Dev. 12, 30-35.

14. Kolch, W. 2005. Coordinating ERK/MAPK signalling through scaffolds and inhibitors. Nat. Rev. Mol. Cell Biol. 6, 827-837.

15. Kureishy, N., V. Sapountzi, S. Prag, N. Anilkumar, and J. C. Adams. 2002. Fascins, and their roles in cell structure and function. Bioessays. 24, 350-361.

16. Melnick, M. B., L. A. Perkins, M. Lee, L. Ambrosio, and N. Perrimon. 1993. Developmental and molecular characterization of mutations in the Drosophilaraf serine/threonine protein kinase. Development 118, 127-138.

17. Otto, J. J., R. E. Kane, and J. Bryan. 1979. Formation of filopodia in coelomocytes: localization of fascin, a 58,000 dalton actin cross-linking protein. Cell 17, 285-293.

18. Paterson, J. and K. O'Hare. 1991. Structure and transcription of the singed locus of Drosophila melanogaster. Genetics 129, 1073-1084.

19. Patwari, P. and R. T. Lee. 2008. Mechanical control of tissue morphogenesis. Circ. Res. 103, 234-243.

20. Phelps, C. B. and A. H. Brand. 1998. Ectopic gene expression in Drosophila using GAL4 system. Methods 14, 367-379.

21. Ramos, J. W. 2008. The regulation of extracellular signalregulated kinase (ERK) in mammalian cells. Int. J. Biochem Cell Biol. 40, 2707-2719.

22. Xie, J., J. Qian, J. Yang, S. Wang, M. E. Freeman $3^{\text {rd }}$, and Q. Yi. 2005. Critical roles of Raf/MEK/ERK and PI3K/AKT signaling and inactivation of p38 MAP kinase in the differentiation and survival of monocyte-derived immature dendritic cells. Exp. Hematol. 33, 564-572.

초록 : Raf 신호에 의한 초파리 fascin의 조절

표정훈·최나현 · 이신해·김영신 · 유미애x

(부산대학교 자연과학대학 분자생물학과)

Fascin은 액틴결합 단백질로 형성을 포함한 많은 발생과정에 있어서 중요한 역할을 한다. Fascin은 암세포에 대한 생체표지인자로도 잘 알려져 있다. 그러나 이러한 fascin 유전자의 발현조절기전은 현재까지 잘 알려져 있지 않다. 본 연구에서는 Raf돌연변이 초파리에서 이미 보고 되어있는 초파리 fascin 돌연변이 초파리의 휘어진 등털 표현형을 관찰함으로써 초파리 fascin 유전자의 발현이 Raf신호체계에 의해 조절되는 가를 조사하였다. RT-PCR과 Western blot의 실험방법으로 Raf 유전자 돌연변이 초파리에서 fascin의 발현이 감소되어 있는 것을 확인하였으며, GAL4-UAS계로 Raf를 과발현시킨 초파리에서 Fascin 발현이 증가하는 것을 확인할 수 있었다. 또한 세포의 증식과 이동 연구모델계로 잘 알려져 있는 초파리의 혈액세포에서 이러한 조절기전을 확인하였다. 이러한 결과들은 fascin 유전자의 발현이 Raf 신호체계에 의해 조절된다는 것을 나타낸다. 